Perwira Journal of Economics and Business

(PJEB) E-ISSN : 2775-572X

Volume 1 Nomor 1

Februari 2021

\title{
THE INFLUENCE OF ORGANIZATION CULTURE AND \\ INTERNAL AUDIT ON GOOD GOVERNANCE \\ (Survey in Government Office of Banyumas City)
}

\author{
Destin Alfianika Maharani' ${ }^{1}$, Ika Siti Fatimah ${ }^{2}$ \\ 1,2 Universitas Perwira Purbalingga \\ Email Koresponden. destinmaharani@gmail.com
}

\begin{abstract}
This study aims to determine the influence of internal audit and organizational culture on the realization of good governance. The type of research methods used by the author is used by the writer is a study that is descriptive and associative. Descriptive analysis method is a research conducted to determine the value of independent variables, either one variable or more (independent) without making comparisons or connecting with other variables while associative analysis is research that aims to determine the relationship of two variables or more. Based on the results of the study note that organizational culture affects the variable good governance of $41.6 \%$ with a significance value of 0.009. Furthermore, internal audit affects good governance variable of $54.8 \%$ with a significance value of 0.002 . Then organizational culture and internal audit able to explain variable good governance equal to $72 \%$. with a significance value of 0.000 .
\end{abstract}

Keywords: organizational culture, internal audit and good governance

\section{PENDAHULUAN}

Budaya organisasi kini sedang menjadi pembicaraan di mana-mana, baik di kalangan para pakar maupun di kalangan para praktisi bisnis dan para eksekutif, karena budaya organisasi tersebut banyak yang berhasil membuat suatu organisasi menjadi lebih stabil, lebih maju, lebih antisipatif terhadap perubahan lingkungan.

Suatu budaya organisasi yang kuat dan telah berakar akan dapat memberikan kontribusi yang cukup signifikan bagi anggota organisasi dalam hal pemahaman yang jelas dan lugas tentang suatu persoalan yang diselesaikan. Budaya memiliki pengaruh yang berarti pada sikap dan perilaku anggota-anggota organisasi. Banyak bukti yang menggambarkan bahwa suksesnya suatu organisasi disebabkan karena budayanya yang begitu kuat yang membuat organisasi itu lebih percaya diri dan akhirnya menjadi lebih efektif. Dalam era globalisasi yang sangat sarat dengan perubahan, perubahan mana sering begitu cepat dan sangat sulit diprediksi namun sangat besar dampaknya bagi masa depan organisasi, kehadiran budaya organisasi yang fleksibel menjadi semakin relevan. Strategi dalam mengantisipasi perubahan yang akan dilakukan oleh suatu organisasi juga perlu mempertimbangkan aspek budaya yang telah ada selama ini, apakah strategi yang didesain tersebut cocok dengan nilai-nilai yang ada, atau justru nilai-nilai yang ada justru itu menjadi kontra produktif bagi organisasi dalam perjalanannya ke depan. Para manajer terutama yang berada pada level puncak mesti sadar betapa pentingnya memahami budaya organisasinya karena pengaruhnya yang begitu besar terhadap perilaku anggota. Budaya organisasi juga dapat dipakai sebagai konsep dalam menyusun 
strategi perubahan atau pengembangan organisasi yang dipimpinnya.

Budaya organisasi terutama dalam suatu lembaga memegang peranan penting. Sebab akan menjadikan lembaga tersebut lentur, fleksibel dan elastis, sebagaimana budaya yang tidak akan pernah mengalami kejumudan dan akan menjadi sangat sempurna jika dipadu dengan agama yang bersumber pada wahyu Ilahi.

Audit internal adalah suatu fungsi penilaian independen yang dibuat organisasi dengan tujuan untuk menguji dan mengevaluasi berbagai kegiatan yang dilaksanakan organisasi. Sedangkan tujuan dilaksanakannya audit internal adalah untuk memperbaiki kinerja organisasi dengan cara membantu karyawan organisasi agar mereka dapat melaksanakan tanggung jawabnya secara efektif. Pelayanan publik prima yang berkualitas merupakan salah satu elemen penting dalam penegakan prinsip-prinsip tata pemerintahan yang baik atau good governance.

Mengingat pengembangan good governance memiliki kompleksitas yang tinggi dan kendala yang besar maka diperlukan sebuah langkah startegis untuk memulai pembaharuan praktik governance. Pengembangan good governance akan dirasa lebih mudah jika dimulai dari sektor pelayanan publik. Pelayanan publik dipilih sebagai penggerak utama dan entry point karena upaya mewujudkan nilai-nilai yang selama ini mencirikan praktik praktik good governance dalam pelayanan publik dapat dilakukan secara lebih nyata dan mudah. Nilai-nilai seperti efisiensi, transparansi, akuntabilitas dan partisipasi dapat diterjemahkan secara relatif lebih mudah dalam penyelenggaraan layanan publik.

Kabupaten Banyumas juga meraih WTP Setelah menerima Laporan Hasil Pemeriksaan (LHP) atas Laporan Keuangan Pemerintah Daerah (LKPD), Kabupaten Banyumas kembali bisa mempertahankan hasil tertinggi yaitu mendapat Opini Wajar Tanpa Pengecualian (WTP) atas Laporan Keuangan Pemerintah Daerah Tahun 2019 dan ini merupakan WTP yang Ke-Tujuh kalinya, walaupun dengan menggunakan sistem pengelolaan keuangan yang baru yaitu akrual basic di dua tahun belakangan ini, namun hal ini tidak menjadi kendala tetapi sebaliknya malah menjadi anugerah sekaligus yang sangat besar untuk lebih meningkatkan kinerja, sebab mempertahankan bukan hal yang mudah.

$$
\text { Fenomena yang terjadi di }
$$

Kabupaten Banyumas pascapemekaran dimana Pemerintah Kota (Pemda) Banyumas meluncurkan berbagai kebijakan sosial yang bertendensi untuk meningkatkan kapabilitas dan kemampuan ekonomi masyarakat, utamanya masyarakat miskin. Fenomena ini sebetulnya bukan sama sekali baru. Beberapa daerah di Indonesia pada era desentralisasi membangun kebijakan-kebijakan sosial yang berpihak pada peningkatan kesejahteraan masyarakat miskin. Namun demikian, hingga kini belum ada eksplanasi teoritik yang dapat menjelaskan secara memadai fenomena tersebut. Untuk menjawab pertanyaan tersebut, studi ini menjadikan pengalaman Kabupaten Banyumas sebagai kasus. Pemda Banyumas meluncurkan tiga kebijakan sosial utama, yaitu kebijakan sosial di sektor pendidikan, kesehatan, dan pedesaan. Kebijakan sosial tersebut ditopang pula dengan pembangunan infrastruktur, baik infrastruktur sektoral (pendidikan, kesehatan, dan pedesaan) maupun infrastruktur perkotaan untuk memuluskan roda perekonomian di daerah tersebut. Studi ini menggunakan kerangka kerja yang disusun oleh Jayasuriya (2006). Menurut Jayasuriya, kebijakan sosial di negara-negara berkembang lahir atas kebutuhan rejim neoliberalisme global untuk mengintegrasikan kewargaan (citizenship) ke dalam pasar. Kebijakankebijakan sosial yang ditujukan untuk meningkatkan kesejahteraan masyarakat, utamanya masyarakat miskin, difokuskan untuk meningkatkan kapabilitas masyarakat agar selaras dan sejalan dengan kebutuhan pasar. Karena dibangun di atas fondasi kewargaan pasar (market 
citizenship) semacam itu, dan bukan melalui pembentukan pakta sosial yang berlangsung dalam negosiasi yang alot antara negara, warga, dan pasar, maka pola kebijakan sosial di negara berkembang menunjukkan watak yang antipolitik dan menonjolkan peran agen yang aktif.

\section{KAJIAN TEORI}

Menurut John R. dan James G. Hunt (1991:340) dalam Anwar (2008:113) mengemukakan bahwa: "Organizational culture is the system of shared beliefs and values that develops within an organization and guides the behavior of its members." Pernyataan tersebut menjelaskan bahwa budaya organisasi adalah sistem bersama keyakinan dan nilai yang berkembang dalam sebuah organisasi dan panduan perilaku anggotanya. Sedangkan menurut Edgar H.Schein (1992:21) dalam Anwar (2008:113) berpendapat bahwa : "An organization's culture is a pattern of basic assumptions invented, discovered on developed by a given group as it learns to cope with is problems of external adaption and internal integration that has worked well enough to be considered valid and to be taught to new members as the correct way to perceive, think and feel in relation to these problems."

Pernyataan diatas menjelaskan bahwa budaya organisasi adalah suatu pola dimensi milik bersama yang dipelajari suatu kelompok pada suatu saat memecahkan masalah adaptasi eksternal dan integrasi internal, yang telah cukup berhasil dan arena itu, akan diajarkan kepada anggota kelompok yang baru sebagai cara yang benar untuk mempersepsi, berfikir, dan merasa dalam menghadapi masalah serupa. Berdasarkan pengertian diatas maka dapat disimpulkan bahwa pengertian budaya organisasi adalah seperangkat asumsi atau sistem keyakinan, nilai-nilai dan norma yang dikembangkan dalam organisasi yang dijadikan pedoman tingkah laku bagi anggota-anggotanya untuk mengatasi masalah adaptasi eksternal dan integrasi internal.
Fungsi budaya organisasi dapat membantu mengatasi masalah adaptasi eksternal dan integrasi organisasi. Hal ini sesuai dengan pendapat John R. dan James G. (1991:344) bahwa: "The culture of an organization can help it deal with problems of both eksternal adaption and internal itegration."

Permasalahan yang berhubungan dengan adaptasi eksternal dapat dilakukan melalui pengembangan pemahaman tentang strategi dan misi organisasi, tujuan utama organisasi dan pengukuran kinerja. Sedangkan permasalahan yang berhubungan dengan integrasi internal dapat dilakukan antara lain komunikasi, kriteria karyawan, penentuan standar bagi insentif dan sanksi serta melakukan pegawasan internal organisasi ( Anwar 2008:123).

Audit internal yang digunakan sebagai suatu cara untuk mencegah kecurangan yang kegiatannya meliputi menguji dan menilai efektivitas serta kesesuaian sistem pengendalian internal yang ada dalam organisasi. Fungsi audit internal ini dalam suatu kementerian dapat berupa divisi, departemen, fungsi bisnis, proses bisnis, layanan informasi, dan sistem. Tanpa audit internal, dewan direksi atau pimpinan unit tidak akan memiliki sumber informasi internal yang bebas mengenai kinerja organisasi. Auditor internal berfungsi membantu manajemen dalam pencegahan, pendeteksian dan penginvestigasian fraud yang terjadi di suatu organisasi (organisasi). Sesuai Interpretasi Standar Profesional Audit Internal (SPAI) - standar 120.2 tahun 2004, tentang pengetahuan mengenai kecurangan, dinyatakan bahwa auditor internal harus memiliki pengetahuan yang memadai untuk dapat mengenali, meneliti dan menguji adanya indikasi kecurangan.

Audit internal merupakan pengawasan manajerial yang fungsinya mengukur dan mengevaluasi sistem pengendalian dengan tujuan membantu semua anggota manajemen dalam mengelola secara efektif pertanggungjawabannya dengan cara 
menyediakan analisis, penilaian, rekomendasi, dan komentar-komentar yang berhubungan dengan kegiatan- kegiatan yang ditelaah. Ikatan Auditor Internal (Institute of Internal Auditors - IIA) dikutip oleh Messier (2005: 514), mendefinisikan audit internal sebagai berikut : "Audit intern adalah aktivitas independen, keyakinan obyektif, dan konsultasi yang dirancang untuk menambah nilai dan meningkatkan operasi organisasi. Audit intern ini membantu organisasi mencapai tujuannya dengan melakukan pendekatan sistematis dan disiplin untuk mengevaluasi dan meningkatkan efektivitas manajemen resiko, pengendalian, dan proses tata kelola.

Menurut Hery (2010:39) tujuan dari audit internal secara umum memiliki tujuan untuk membantu segenap anggota manajemen dalam menyelesaikan tanggung jawab mereka secara efektif, dengan member mereka analisis, penilaian, saran dan komentar yang objektif mengenai kegiatan atau hal-hal yang diperiksa

Good governance pada dasarnya adalah suatu konsep yang mengacu kepada proses pencapaian keputusan dan pelaksanaannya yang dapat dipertanggungjawabkan secara bersama. Sebagai suatu konsensus yang dicapai oleh pemerintah, warga negara, dan sektor swasta bagi penyelenggaraan pemerintahaan dalam suatu negara. Pelaksanaan Good Governance perlu dilakukan secara sistematis dan berkesinambungan. Untuk itu diperlukan pedoman praktis yang dapat dijadikan acuan oleh organisasi dalam melaksanakan Good Governance. Untuk melaksanakan Good Governance diperlukan penyusunan pedoman Good Governance yang spesifik untuk masing-masing organisasi.

\section{Kerangka Pemikiran}

Organisasi Pemerintah Daerah (OPD) serta penyusunan struktur organisasi pada Satuan Kerja Perangkat Daerah (SKPD) saat ini dilakukan berdasarkan pada kerangka regulasi serta kebutuhan obyektif dan kondisi lingkungan strategis daerah. Kerangka regulasi yang dimaksud adalah Peraturan Pemerintah No. 41 tahun 2007 sebagai perubahan terhadap Peraturan Pemerintah sebelumnya.

Dasar utama penyusunan organisasi perangkat daerah dalam bentuk suatu organisasi adalah adanya urusan pemerintahan yang menjadi kewenangan daerah, yang terdiri atas urusan wajib dan urusan pilihan , namun tidak berarti setiap penanganan urusan pemerintahan harus dibentuk kedalam organisasi tersendiri. Pembentukan perangkat daerah sematamata didasarkan pada pertimbangan rasional untuk melaksanakan urusan pemerintahan yang menjadi kewenangan daerah secara efektif dan efisien.

Selain PP No. 41/2007, penataan kelembagaan perangkat daerah juga memperhatikan peraturan perundangundangan yang memiliki relevansi dengan program penataan organisasi.

Berdasarkan UU No. 23 tahun 2014 tentang Pemerintah Daerah, perangkat daerah propinsi dan Kabupaten/ Kota ditetapkan melalui Peraturan Daerah.

Di Kabupaten Banyumas regulasi yang mengatur tentang Organisasi Pemerintah Daerah (OPD) tertuang di dalam Peraturan Walikota No 30 tahun 2016, dimana terdiri dari 17 dinas daerah, 2 lembaga dan 3 badan daerah

Penelitian yang berkaitan dengan pengaruh good governance, pengendalian intern dan budaya organisasi terhadap kinerja pemerintah daerah

telah dilakukan oleh beberapa peneliti sebelumnya. Nur Azlina \& Desmiyawati (2012) meneliti Pengaruh komitmen organisasi, pengendalian intern dan akuntabilitas publik terhadap good governance, hasilnya menunjukkan akuntabilitas publik tidak memediasi pengaruh komitmen organisasi terhadap kinerja organisasi dan juga tidak memediasi pengaruh pengendalian intern terhadap kinerja organisasi. Penelitian yang sama dilakukan oleh Prima Yuda (2012) yang meneliti mengenai Pengaruh Good Governance dan Pengendalian Intern 
Terhadap Kinerja Organisasi. Abdullah dan Herlin Arisanti (2010) meneliti Pengaruh Budaya Organisasi, Komitmen Organisasi dan Akuntabilitas Publik terhadap Kinerja Organisasi. Hasil penelitiannya menyimpulkan budaya organisasi berpengaruh terhadap good governance.

Secara lebih spesifik, organisasi mengandalkan fungsi audit intern untuk membantu memastikan bahwa proses manajemen risiko, lingkup pengendalian secara keseluruhan dan efektivitas kinerja dari proses usaha telah konsisten dengan ekspektasi manajemen. Fungsi audit internal saat ini tidak sekedar dituntut menemukan permasalahan namun sekaligus menjadi bagian dari solusi dan memberikan usulan perbaikan. Dengan demikian, peran audit internal tidak hanya sebatas sebagai "detector" namun bisa lebih yaitu sebagai pencegah yang diharapkan mampu mendukung dan mendorong proses terwujudnya good governance

Definisi diatas menggambarkan fungsi dari audit internal yang memeriksa seluruh kegiatan dan kecermatan pembukuan dan data lainnya yang dihasilkan oleh organisasi. Hal itu bertujuan untuk mengetahui apakah laporan keuangan yang disajikan oleh organisasi telah dilaporkan dengan benar dan sesuai dengan standar yang telah berlaku umum.

Apabila budaya organisasi diterapkan dan disosialisasikan secara baik, maka dapat memberi arah bagi setiap anggota organisasi, untuk mencapai produktivitas kerja yang lebih tinggi sehingga tujuan organisasi tercapai seseuai dengan asas-asas Good Governance.

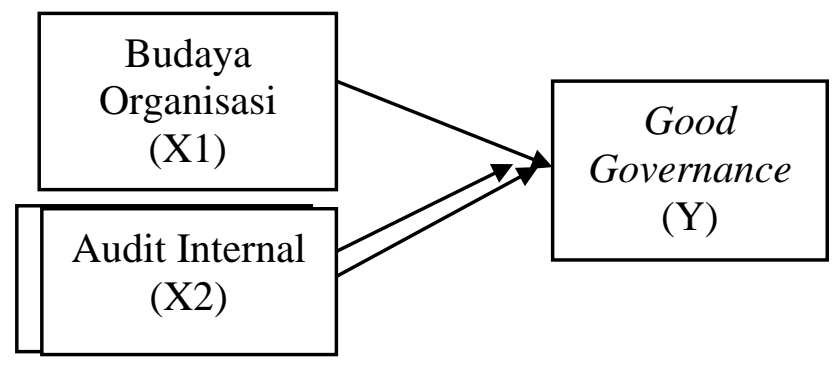

Hipotesis yang diajukan dalam penelitian ini adalah :
1) Budaya Organisasi berpengaruh signifikan secara parsial terhadap Good Governance.

2) Audit Internal berpengaruh signifikan secara parsial terhadap Good Governance.

3) Budaya Organisasi dan Audit Internal berpengaruh signifikan secara simultan terhadap Good Governance.

\section{METODE PENELITIAN.}

Metode yang digunakan dalam penelitian ini adalah eksplanatori. Populasi penelitian yang penulis teliti adalah subjek yang berhubungan dengan budaya organisasi dan audit internal, dalam kaitannya dengan good governance organisasi yaitu Satuan Kerja Perangkat Daerah di Pemerintah Kabupaten Banyumas. Penentuan sampel menggunakan non profibility sampling, yaitu apabila setiap elemen populasi tidak mempunyai kesempatan yang sama untuk terpilih sebagai sempel. Penelitian ini menggunakan cara mengumpulkan informasi dan elemen populasi yang tersedia pada saat dilakukannya penelitian. Alasan menggunakan metode ini dikarenakan keterbatasan jumlah kantor dinas yang bersedia berpartisipasi untuk dijadikan sebagai responden. Sampel penelitian yang digunakan oleh penulis dengan menggunakan kuesioner sebagai alat pengumpulan data adalah sebanyak 15 dinas. Penelitian ini menggunakan metode pengumpulan sumber data dengan cara mengumpulkan kuesioner yang telah di sebar di Dinas Kabupaten Banyumas dan kemudian jawaban dari responden yang ikut berpartisipasi dalam penelitian ini sehingga menghasilkan data primer dari auditor yang ikut berpartisipasi dalam penelitian ini. Analisis regresi berganda dilakukan untuk menguji pengaruh simultan dari beberapa variabel bebas terhadap satu variabel terikat dengan skala interval. Dengan kata lain analisis regresi berganda membantu dalam memahami berapa varian dalam variabel terikat yang dijelaskan 
HASIL PENELITIAN DAN PEMBAHASAN

\section{Pengaruh Budaya Organisasi terhadap Good governance}

Dalam perhitungan yang penulis lakukan untuk mengetahui ada tidaknya pengaruh Budaya Organisasi terhadap Good governance pada Dinas Pemerintah Kabupaten Banyumas dapat diketahui dan dihitung menggunakan SPSS. Dari hasil pengolahan data didapat nilai koefisien korelasi (r) sebesar 0,645. Artinya pengaruh Budaya Organisasi terhadap Good governance dengan kategori kuat. Selanjutnya dari hasil uji koefisien determinasi didapatkan hasil bahwa nilai $\mathrm{r}^{2}$ adalah sebesar 0,416. Hal ini berarti besarnya peran atau kontribusi variabel independen Budaya Organisasi mampu menjelaskan variabel Good governance sebesar 41,6\%.

Hasil perhitungan dengan menggunakan SPSS versi 23 diperoleh nilai $\mathrm{t}_{\text {hitung }}$ sebesar 3,046. Pada perhitungan nilai $\mathrm{dk}=\mathrm{n}-2=15-2=13$ didapat $\mathrm{t}_{\text {tabel }}$ sebesar 1,771. Jika dibandingkan dengan $t_{\text {tabel }}$ maka diperoleh bahwa $t_{\text {hitung }}(3,046)>t_{\text {tabel }}$ $(1,771)$ Dan dilihat dari signifikasinya diperoleh hasil uji sig. sebesar 0,009 lebih kecil dari tingkat $\alpha=0,05$.

Karena $\mathrm{t}_{\text {hitung }}>\mathrm{t}_{\text {tabel }}$ atau karena nilai sig 0,009 lebih kecil dari $\alpha=0,05$, maka hasil pengujian tersebut mengandung makna bahwa kaidah keputusan Ho ditolak dan Ha diterima. Hal tersebut menunjukkan bahwa pada tingkat keyakinan 95\% hipotesis alternatif diterima artinya Budaya Organisasi berpengaruh signifikan terhadap Good governance

Dari hasil penelitian di atas menunjukan bahwa budaya organisasi berpengaruh signifikan terhadap good governance pemerintah daerah pada Pemerintah Kabupaten Banyumas yang memiliki pengaruhnya $41,6 \%$. Ini artinya bahwa, semakin baik budaya organisasi yang dimiliki maka semakin baik pula kualitas good governance pada pemerintah daerah, oleh karena itu dibutuhkan nilainilai yang berlaku di organisasi serta menumbuhkan rasa toleransi dalam menjalankan tugas, khususnya yang berkaitan dengan perbedaan pendapat dan perbedaan sifat individu yang berbeda-beda.

Menurut Sentot Imam (2010:34) bahwa budaya organisasi mengacu pada kesatuan sistem makna bersama yang dianut oleh anggota-anggota yang membedakan organisasi itu dari organisasi-organisasi lain. Budaya perusahaan yang baik adalah budaya yang sesuai dengan sistem nilai yang diyakini oleh semua anggota organisasi, dipelajarai, ditetapkan, serta dikembangkan secara berkesinambungan, berfungsi sebagai perekat, dan dapat dijadikan acuan berperilaku untuk mencapai tujuan organisasi atau perusahaan. Budaya yang kuat adalah budaya yang mampu mengikat seluruh anggota organisasi, menjadi sistem perekat, menjadi milik bersama. Apabila budaya organisasi diterapkan dan disosialisasikan secara baik, maka dapat memberi arah bagi setiap anggota organisasi, untuk mencapai produktivitas kerja yang lebih tinggi sehingga tujuan organisasi tercapai seseuai dengan asas-asas Good Governance

Hasil ini sejalan dengan penelitian Keith Kefgen and Manav Thadani, (2003) bahwa budaya perusahaan menunjukkan bagian yang tak terpisahkan dari mentalitas governance dari suatu perusahaan. Selanjutnya Mas Achmad Daniri (2005) menyatakan keberhasilan penerapan good governance tersebut tidak terlepas dipengaruhi faktor internal dan eksternal organisasi. Faktor internal adalah berbagai faktor yang berasal dari dalam perusahaan, salah satunya adalah budaya organisasi. Selain itu Mardiasmo,D.,et.al, (2008:97) menyatakan bahwa budaya pemerintahan daerah merupakan variabel rintangan utama dalam pelaksanaan good governance

\section{Pengaruh Audit Internal terhadap Good governance}


Dalam perhitungan yang penulis lakukan untuk mengetahui ada tidaknya pengaruh Audit Internal terhadap Good governance pada Dinas Pemerintah Kabupaten Banyumas dapat diketahui dan dihitung menggunakan SPSS versi 23. Dari hasil pengolahan data didapat nilai koefisien korelasi (r) sebesar 0,740. Artinya pengaruh Audit Internal terhadap Good governance dengan kategori sangat kuat. Selanjutnya dari hasil uji koefisien determinasi didapatkan hasil bahwa nilai $\mathrm{r}^{2}$ square adalah sebesar 0,548. Hal ini berarti besarnya peran atau kontribusi variabel independen Audit Internal mampu menjelaskan variabel Good governance sebesar $54,8 \%$.

Hasil perhitungan dengan menggunakan SPSS diperoleh nilai $\mathrm{t}_{\text {hitung }}$ sebesar 3,972. Pada perhitungan nilai $\mathrm{dk}=\mathrm{n}$ $-2=15-2=13$ didapat $t_{\text {tabel }}$ sebesar 1,771. Jika dibandingkan dengan $t_{\text {tabel }}$ maka diperoleh bahwa $t_{\text {hitung }}(3,972)>t_{\text {tabel }}$ $(1,771)$ Dan dilihat dari signifikasinya diperoleh hasil uji sig. sebesar 0,002 lebih kecil dari tingkat $\alpha=0,05$.

Karena $t_{\text {hitung }}>\mathrm{t}_{\text {tabel }}$ atau karena nilai sig 0,002 lebih kecil dari $\alpha=0,05$, maka hasil pengujian tersebut mengandung makna bahwa kaidah keputusan Ho ditolak dan Ha diterima. Hal tersebut menunjukkan bahwa pada tingkat keyakinan 95\% hipotesis alternatif diterima artinya audit internal berpengaruh signifikan terhadap Good governance.

Dari hasil penelitian di atas menunjukan bahwa Audit Internal berpengaruh signifikan terhadap good governance pemerintah daerah pada Pemerintah Kabupaten Banyumas yang memiliki pengaruhnya $54,8 \%$. Ini artinya bahwa, semakin baik Audit Internal yang dilakukan maka semakin baik pula kualitas good governance pada pemerintah daerah, oleh karena itu dibutuhkan jaminan, independen, obyektif dan aktivitas konsultasi yang dirancang untuk menambah nilai dan meningkatkan operasi organisasi.
Ini membantu organisasi mencapai tujuannya dengan membawa pendekatan yang sistematis dan disiplin untuk mengevaluasi dan meningkatkan efektivitas proses manajemen risiko, pengendalian, dan proses governance. Sesuai dengan pendapat Gumilang (2010:32) bahwa: Eksistensi audit internal merupakan salah satu perwujudan dari Good Governance. Selain itu audit internal berperan sangat strategis dalam membantu manajemen dalam upaya mewujudkan Good Governance ke dalam praktek-praktek bisnis manajemen.

Praktik Good Governance adalah seperangkat kebijakan, aturan, sistem dan prosedur yang dirancang sendiri oleh perusahaan serta kebijakan dan aturan yang ditetapkan oleh eksternal perusahaan yang mendorong terciptanya hubungan yang harmonis, partisipatif, adil antara perusahaan dengan stakeholdenya serta mendorong pengelolaan perusahaan secara transparan dan dapat dipertanggungjawabkan. Agar Good Governance dapat tercipta harus ada keterlibatan dan kesungguhan dari berbagai pihak (internal dan eksternal perusahaan) (Sulaeman, Maman, 2018), Perwujudan Good Governance ternyata sangat membutuhkan peran akuntan perusahaan, baik itu peran akutan manajemen maupun peran auditor internal. Secara garis besar audit internal adalah suatu fungsi penilaian yang dikembangkan secara bebas dalam organisasi untuk menguji dan mengevaluasi kegiatan-kegiatan sebagai wujud pelayanan terhadap organisasi perusahaan. Selain itu audit internal merupakan aktivitas penjaminan yang independen dan objektif serta jasa konsultasi yang dirancang untuk memberikan nilai tambah dan meningkatkan prestasi organisasi.

Penelitian yang mendukung dari penelitian sebelumnya yang dilakukan Dhimas Nugraha (2012), menunjukan bahwa pelaksanaan audit internal menunjukkan adanya pengaruh yang signifikan dalam mewujudkan good corporate governance. Hal ini dikarenakan adanya pelaksanaan audit internal yang 
sesuai dengan standar audit yang berlaku dan sesuai dengan tahap-tahap audit internal, maka akan dapat meningkatkan prinsip transparansi dan akuntabilitas pada good corporate governance. Selanjutnya menurut Vicky Dzaky (2014), menunjukan bahwa audit internal memiliki pengaruh yang positif atau signifikan terhadap penerapan good corporate governance. Hal ini dikarenakan audit internal dan good corporate governance memiliki hubungan yang sangat erat dimana audit internal sebagai orang dalam bagian harus dapat menerapkan tata kelola perusahaan yang baik guna mencapai tujuan dan sasaran yang telah ditetapkan oleh perusahaan. Keberadaan audit internal sangat penting dalam memastikan terlaksananya nilai nilai etika dalam mencapai good corporate governance sehubungan dengan adanya berbagai macam kasus yang terjadi baik di Indonesia maupun di luar Indonesia

\section{Pengaruh Budaya Organisasi dan Audit Internal secara simultan terhadap Good governance}

Dalam perhitungan yang penulis lakukan untuk mengetahui ada tidaknya pengaruh budaya organisasi dan Audit Internal terhadap Good governance pada Dinas Pemerintah Kabupaten Banyumas dapat diketahui dan dihitung menggunakan SPSS versi 23. Dari hasil pengolahan data didapat nilai koefisien korelasi (r) sebesar 0,849 . Artinya pengaruh budaya organisasi dan Audit Internal terhadap Good governance dengan kategori sangat kuat. Selanjutnya dari hasil uji koefisien determinasi didapatkan hasil bahwa nilai $\mathrm{r}^{2}$ adalah sebesar 0,720. Hal ini berarti besarnya peran atau kontribusi variabel independen budaya organisasi dan Audit Internal mampu menjelaskan variabel Good governance sebesar $72 \%$.

Hasil perhitungan dengan menggunakan SPSS diperoleh nilai $\mathrm{F}_{\text {hitung }}$ sebesar 15,451. Pada perhitungan nilai $\mathrm{dk}=$ $\mathrm{n}-\mathrm{k}=15-3=12$ didapat $\mathrm{F}_{\text {tabel }}$ sebesar 3,086. Jika dibandingkan dengan $\mathrm{F}_{\text {tabel }}$ maka diperoleh bahwa $\mathrm{F}_{\text {hitung }}(15,451)>\mathrm{F}_{\text {tabel }}$
$(3,086)$ Dan dilihat dari signifikasinya diperoleh hasil uji sig. sebesar 0,000 lebih kecil dari tingkat $\alpha=0,05$.

Karena $\mathrm{F}_{\text {hitung }}>\mathrm{F}_{\text {tabel }}$ atau karena nilai sig 0,000 lebih kecil dari $\alpha=0,05$, maka hasil pengujian tersebut mengandung makna bahwa kaidah keputusan Ho ditolak dan Ha diterima. Hal tersebut menunjukkan bahwa pada tingkat keyakinan 95\% hipotesis alternatif diterima artinya Budaya Organisasi dan audit internalberpengaruh signifikan terhadap Good governance.

Dari hasil penelitian di atas menunjukan bahwa budaya organsiasi dan Audit Internal berpengaruh signifikan terhadap good governance pemerintah daerah pada Pemerintah Kabupaten Banyumas yang memiliki pengaruhnya $72 \%$. Ini artinya bahwa, semakin baik budaya organsiasi dan Audit Internal yang dilakukan maka semakin baik pula kualitas good governance pada pemerintah daerah, oleh karena itu dibutuhkan jaminan, independen, obyektif dan aktivitas konsultasi yang dirancang untuk menambah nilai dan meningkatkan operasi organisasi. Ini membantu organisasi mencapai tujuannya dengan membawa pendekatan yang sistematis dan disiplin untuk mengevaluasi dan meningkatkan efektivitas proses manajemen risiko, pengendalian, dan proses governance.

Hal ini sesuai dengan pendapat Cartwright dalam Djokosantoso (2006:148) "Bahwa budaya (perusahaan) adalah "a powerful determinant of people's beliefs, attitudes, and behavior". Budaya perusahaan yang baik menjadi determinan dari tata kelola usaha yang baik, terbentuknya dan berkembangnya manajemen profesional, kuatnya komitmen tanggung jawab sosial dari perusahaan kepada lingkungannya, dan semangat untuk menjaga keunggulan korporasi."

Secara lebih spesifik, organisasi mengandalkan fungsi audit intern untuk membantu memastikan bahwa proses manajemen risiko, lingkup pengendalian secara keseluruhan dan efektivitas kinerja 
dari proses usaha telah konsisten dengan ekspektasi manajemen. Fungsi audit internal saat ini tidak sekedar dituntut menemukan permasalahan namun sekaligus menjadi bagian dari solusi dan memberikan usulan perbaikan. Dengan demikian, peran audit internal tidak hanya sebatas sebagai "detector" namun bisa lebih yaitu sebagai pencegah yang diharapkan mampu mendukung dan mendorong proses terwujudnya good governance.

Penelitian yang sama dilakukan oleh Prima Yuda (2012) yang meneliti mengenai Pengaruh Good Governance dan Pengendalian Intern Terhadap Kinerja Organisasi. Abdullah dan Herlin Arisanti (2010) meneliti Pengaruh Budaya Organisasi, Komitmen Organisasi dan Akuntabilitas Publik terhadap Kinerja Organisasi. Hasil penelitiannya menyimpulkan budaya organisasi dan audit internal berpengaruh terhadap good governance.

\section{Simpulan}

1. Budaya Organisasi pada Dinas di Kabupaten Banyumas termasuk kategori baik dengan indikator kemampuan dalam pengawasan (supervisory ability) dan kebutuhan akan penghargaan (Need for reward). Audit Internal pada Dinas di Kabupaten Banyumas baru termasuk kategori baik pada indikator kuantitas kerja. Good Governance pada Dinas di Kabupaten Banyumas baru termasuk kategori baik pada indikator responsif.

2. Terdapat pengaruh signifikan secara parsial Budaya Organisasi dan Auidt Internal terhadap Good governance pada Dinas di Kabupaten Banyumas

3. Terdapat pengaruh signifikan secara simultan Budaya Organisasi dan Audit Internal terhadap Good governance pada Dinas di Kabupaten Banyumas

\section{Saran}

1. Untuk meningkatkan good governance melalui budaya organisasi, sebaiknya kepala dinas menciptakan kepedulian baik atasan terhadap bawahan atau sesama staf agar menimbulkan rasa memiliki organisasi dan memprioritaskan organisasi daripada diri sendiri.

2. Pelaksanaan audit internal sudah dilaksanakan dengan baik akan tetapi masih perlu ditingkatkan dalam hal menyampaikan hasil audit yang telah dilakukan. Dengan demikian auditor perlu menyampaikan hasil audit dengan cara menyampaikan secara transparan dan terbuka sehingga tidak terjadi kesalahpahaman. Kecakapan dan kemampuan teknis auditor internal juga perlu ditingkatkan walaupun memiliki latar belakang pendidikan yang sesuai dengan Standar Profesi Audit Internal, hal ini karena makin peliknya objek pemeriksaan yang dihadapi sehingga perlunya ikut serta dalam pendidikan dan pelatihan secara berkelanjutan. Selanjutnya Auditor Internal belum melaksanakan kebijakan dan prosedur secara tertulis dengan sepenuhnya, hal ini harus selalu dilakukan sebab kebijakan yang tertulis dapat dijadikan acuan dan dipergunakan sebagai pedoman oleh staf pemeriksa, walaupun kebijakan tersebut kadangkala ada perubahan sesuai dengan masa pemeriksaan.

3. Pelaksanaan good governance di Dinas SKPD Kabupaten Banyumas telah dilaksanakan dengan baik. Penulis berharap Pemerintah Kabupaten Banyumas dapat mempertahahankan pelaksanaan prinsip-prinsip good governance dengan lebih baik lagi.

4. Peneliti selanjutnya diharapkan untuk menambah variabel yang dapat mempengaruhi good governance dengan jumlah sampel yang lebih banyak lagi.

\section{DAFTAR PUSTAKA}

Agus Dwiyanto. 2008. Mewujudkan Good Governance melalui Pelayanan Publik. Yogyakarta : Gadjah Mada University Press.

Ambar Teguh Sulistiyani. 2011. Memahami Good Governance: Dalam 
Perspektif Sumber Daya Manusia. Yogyakarta: Gava Media

Anis Chariridan Imam Ghozali.(2003). Teori Akuntansi. Semarang: BP UNDIP.

Arens, Alvin A., Elder, dan Beasley. 2008. Auditing dan Jasa Assurance Pendekatan Terintegrasi Jilid I. Edisi 12. Jakarta: Erlangga

Elizabeth Hanna dan Friska Firnanti (2013). Faktor-faktor yang Mempengaruhi Kinerja Auditor.

Mulyadi, 2002. Auditing, Edisi keenam, Cetakan pertama, Jakarta: Salemba Empat

Sawyer, B.Lawrence et al.2012. Internal Auditing Sawyers, 6th edition.Florida Institute of Internal Auditors

Robbins SP, dan Judge. 2002. Perilaku

Organisasi, Jakarta : Salemba Empat Hal

Sukrisno Agoes. 2004. Auditing (Pemeriksaan Akuntansi), Edisi Ketiga, Fakultas Ekonomi Universitas Indonesia. Jakarta.

Sulaeman, Maman2018Implementation of

GCG In Making Reputation And

CRM, Toward Customer

LoyalityAdvances in Social Science,

Education and Humanities

Research, volume 203265,

International Conference on Life,

Innovation, Change, and Knowledge

(ICLICK 2018)264-267

Suwarto Koeshartono. 2009. Budaya Organisasi; Kajian Konsep dan Implementasi. Yogyakarta: Universitas Atma Jaya

Thereza Michiko Labesi. (2013). Analisis Penerapan Prinsip-Prinsip Good Governance.

Valery G Kumaat, 2011, Internal Audit. Jakarta: Penerbit Erlangga

Kebijakan. Edisikeempat.UPP.STIM.YKPN Yogyakarta.

Karib, Abdul MS. (2012). Analisis Pengaruh Produksi, Investasi dan Unit Usaha Terhadap Penyerapan Tenaga
Kerja Pada Sektor Industri Sumatera Barat. Jurnal Manajemen Dan Kewirausahaan, Volume 3, Nomor 3, September 2012 Issn : 2086-5031. Universitas Andalas. Padang.

Munasriah. (2015). Pengaruh Jumlah Unit Usaha dan Investasi Terhadap Penyerapan Tenaga Kerja Pada Industri Kecil di Kabupaten Wajo. Tesis. Fakultas Ekonomi dan Bisnis. UniversitasHasanuddin.Makasar

Prabandana, R. (2015). Pengaruh Modal, Nilai Produksi dan Tingkat Upah Terhadap Penyerapan Tenaga Kerja Industri Kecil di Kabupaten Sukoharjo. Fakultas Ekonomi dan Bisnis. Universitas Muhammadiyah. Surakarta

Squire, Lyn. (1992). Kebijakan Kesempatan Kerja di Negeri-Negeri Sedang Berkembang: Sebuah Survei, Masalah-Masalah dan Bukti-Bukti, Pustaka Bradjaguna, Jakarta.

Simanjuntak, J. Payaman. (2010). Pengantar Ekonomi Sumber Daya Manusia. Jakarta: Lembaga Penerbit Fakultas Ekonomi Universitas Indonesia.

Sukirno,S.(2002). Pengantar Teori Makroekonommi.Jakarta:PT.Raja Grafindo Persada 